Journal of Awareness

Cilt / Volume 4, Sayı / Issue 3, 2019, pp. 293-304

E - ISSN: 2149-6544

URL: https://www.ratingacademy.com.tr/ojs/index.php/joa

DOİ: https://doi.org/10.26809/joa.4.022

Araştırma Makalesi / Research Article

\title{
THE DIGITAL NECESSITY IN MARKETING EDUCATION TO THE MILLENNIAL GENERATION
}

\author{
Nevenka POPOVIC SEVIC * \& Milica SLIJEPCEVIC ** \\ * Prof. Dr., Information Technology School, SERBIA, \\ E-mail: nevenka.popovic.sevic@its.edu.rs \\ ** Prof. Dr., Metropolitan University, SERBIA, \\ E-mail:milica.slijepcevic@metropolitan.ac.rs
}

Geliş Tarihi: 4 Temmuz 2019; Kabul Tarihi: 24 Temmuz 2019

Received: 4 July 2019; Accepted: 24 July 2019

\begin{abstract}
Higher education institutions nowadays approach important technological challenges that consequently change the students' entire educational world. Universities together with marketing educators are exploring how new digital technologies could be applied as an effective pedagogical tool. This article contributes to the marketing education community in the field of digital necessity for millennial scholars. A broad understanding of students' perceptions and experiences of social media in marketing education is significant for both educational results and student engagements. Adopting such a focus, further reviews represent what students gain from these pedagogical applications and how it will improve their future marketing involvement.
\end{abstract}

Key words: digital technology, marketing education, social media, classroom management, millennial generation. 


\section{INTRODUCTION}

The twenty-first century has unequivocally demonstrated that higher education institutions face great economical, sociological and technological challenges, challenges which require continuous monitoring and adaptation of classroom teaching. Various research on the application of digital technologies in marketing teaching (Rinaldo et al., 2013) and the very positive attitude of students to their new experimental teaching experience (Aviles and Eastman, 2012), speak in favour of the importance of student perceptions and experiences in the use of digital technologies in higher education.

Digital technologies can be characterized as a kind of virtual backbone that enables us to participate in designing content, opinions and experiences with the target audience. In this way, there is certainly an opportunity for a kind of an online interaction between certain communities (groups of people). It is believed that providing various marketing services through digital technologies is a recent trend in the global market. Thus, various educational institutions create diverse educational contents and programs in order to achieve the most direct communication possible with their users and students (Mishra, 2011). Setting up, as well as the subsequent provision of online educational services is an evident and growing need of the present, as technology rapidly advances and users are more inclined to trust Internet databases. Thus, the process of providing marketing services is necessary in order to satisfy all the demands of the user; in this way, digital marketing technologies of today are classified into specific value-added strategies, as they utilize creation, communication, and delivery of value to their user population in exchange for a certain profit.

It is evident that marketing education in higher education institutions should reflect the actual needs of a marketing environment, and should thus be flexible to very turbulent and frequent technological changes in the macro and microenvironment. Innovations in digital technologies do change not only marketing practices but also the way of thinking about marketing. Digital innovations require an added value in immediate marketing education that will imbue marketing practitioners with true expressiveness.

\section{LITERATURE REVIEW}

Over the last decade, it was noticeable that digital technologies have transformed traditional marketing into electronic marketing. Digital media platforms have accordingly been adapting to the marketing strategies that aim to meet the growing needs of their users. There were numerous challenges for all educational workers in terms of the manners of electronic communication with the $20^{\text {th }}$-century users of educational services. Marketing educational services have a wide range of services available to their users: from creating online programs for recruiting their teaching staff, to internal online education, all the way through to providing a wide range of internet modes of teaching, etc. (Rizvi, 2011).

Research of this area includes not only the monitoring of perceptions about the use of digital technologies in educational marketing, the interpretation of the challenges posed to the marketing of educational services through digital media, but also the strategies used by schools to advertise their online educational services (Iqbal, 2016). Educational services can be promoted through various channels, but social networks are believed to be the distinguishing factor between traditional and recent trends in reaching the student population (Tuten and Marks, 2012).

Researchers are also interested in a more precise definition of student experiences regarding what social network tools they see as an effective pedagogical tool, as well as their perception as millennials when it comes to the motives for using digital teaching technologies (Neier and Zayer, 2015). An adequate understanding of student perceptions and experiences 
when using social networks in teaching is extremely important for a better understanding of the overall engagement of students in education. Thanks to a better knowledge of students' attitudes to the latest digital technologies, there are important insights on further upgrading the educational atmosphere.

The focus of digital technologies in marketing education is also evident: 1) a better understanding of the tactical and strategic roles of social networks in teaching marketing, the role and impact of information technology in marketing, the ethical aspects of using new digital technologies in teaching marketing, and 2) development of special technological skills that could be aimed at improving marketing education and preparing students for a more successful involvement in marketing practice after the completion of their studies. Because of these orientations, marketing academics should be maximally flexible in respecting and directly applying available technological innovations.

Previous research has dealt with the topic of teaching, and the conclusion was that, in essence, there are two basic types of learning: formal and informal. Formal learning falls within the traditional knowledge transfer variants created by the educator in such a way that it is rigidly structured and placed in a strictly formal environment with the use of simple learning tools. On the other hand, non-formal learning is not organized or structured by formal learning methods, but is based on the use of the Internet and all digital tools, case studies and other practical examples that are most directly implemented in the teaching process (Gikas and Grant, 2013). Research conducted in American universities, with the involvement of marketing departments, showed that teaching takes place using both formal and informal methods (Brocato et al., 2015). Classical, traditional teaching is dominant (98\%); the next most used method of teaching being the engagement of students by using social networks (63\%). It is interesting that the latter method was not used for student testing, but mostly for teaching purposes.

The previous research has already confirmed the homogeneity of students regarding their active involvement in social networks when it comes to a pedagogical approach to teaching (Hargittai and Litt, 2011), but also an important conclusion that all the millennials (18 to 20 years of age group), as well as those from the 21 to 24 years of age group, spend almost the same amount of time on social networks (Zula et al., 2011).

\section{MILLENNIAL GENERATION}

The millennial generation, otherwise called generation Y, includes those born in 1980 and later. Different authors set different years as caps, so there are discrepancies. The years of birth range from 1995 to 2001. Demographically, these are the children of the Baby Boom generation and the younger brothers and sisters of Generation X (Radojević et al., 2014; Krasulja et al., 2015). Y-generation members are called by different names - The Millennium Generation, The Digital Generation, The "Feel Good" Generation, Cyberkids (Kersten, 2002; Radojević et al., 2014; Krasulja et al., 2015), The Next Generation, The Echo Boomer Generation, The Net Generation and so on (Reynolds, 2008; Andevski and Vučković, 2012; Radojević et al., 2014; Krasulja et al., 2015). Also, we come across names such as digital natives, net-geners, netizens, homo zappiens (Tapscott, 1999; Prensky, 2001; Veen, 2006; Mamula, Radojević and Slijepčević, 2016).

In the aforementioned period, more than 80 million of $\mathrm{Y}$ generation members were born. Statistics show that in the period up to 2020, this generation will make up about $50 \%$ of the world's workforce (Kratz, 2013; Krasulja et al., 2015), and estimates for Serbia indicate that by 2021, they will make up the same number of the total labour force (Mamula, Radojević and Slijepčević, 2016). 
Millennials are the first generation that reached adulthood in the new millennium, hence the popular nickname. They are residents of the digital age and the generation that grew and matured side by side with the development of digital technologies, social media, and mobile devices. The millennials born at the very beginning, 1980-90, are now thirty-year-olds. Some of them already have successful careers, while others will, according to all estimates, become key generators of the world economy in the coming period. Organizations are now faced, among other things, with this challenge, and must create adequate responses and mechanisms that will enable them to adapt effectively and survive on the market (Krasulja et al., 2015), as well as increasingly employing millennials. Given these characteristics, it is very important to analyze all aspects of new generations that are unstoppably conquering the labour market. Krasulja et al., (2015) cite millennials as the main pretenders in the generational shift in the workforce.

Millennials are the first generation that grew up surrounded by digital media (now between 19 and 38 years of age). Online interpersonal interaction and communication have become an important aspect of social activities, especially among millennials (young adults) (Duffett et al., 2016). The millennials are the first generation to know more about the most powerful tools for change, which are digital information and communication technologies (Mamula et al., 2016). In the 2012-2017 period, the time spent by the millennials on the internet during any given day was doubled in just those five years (from 107 minutes in 2012 to the 223 minutes in 2017, www.statsita.com).

Graph 1: The Time Millennials Daily Spend on the Internet, in Minutes

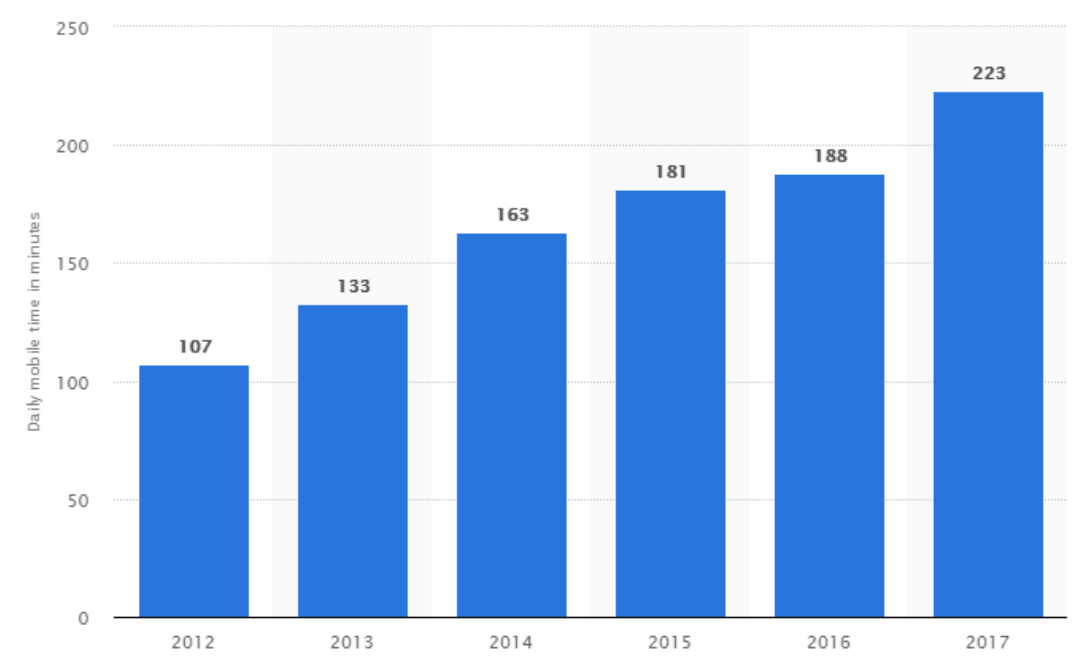

Source: www.statista.com, accessed on April 15, 2019.

Krasulja et al., (2015) state that the character traits of the members of the Millennial Generation are fully shaped by the rapid development of technology and the Internet. According to research and respective results (www.statsita.com), it can be said that they are practically technology-dependent - they look for solutions to their problems on the Internet, communicate through social networks, and expect an immediate response. The author Sago (2010) says that millennials stand out among all other social network users, primarily of Facebook, Twitter, MySpace. Actual communication takes place only through technology (Valcour, 2013; Krasulja et al., 2015).

Millennials often swap roles with their professors/mentors in the course of their schooling in the short term. Interesting creative cooperation between generations, resulting in mutual benefits, is also taking place. Millennials, who are, for the most part, digital experts, often transfer their knowledge and skills to their professors/mentors. The ultimate goal of this reverse mentoring is to improve relationships between different generations, as well as those 
within the same generation, so that everyone has the capacity to change (Mamula et al., 2016). Here again, the prevalent opinion is that millennials are a force for change.

According to the results of the Pew Research Center survey conducted in the US in 2010, conducted on the population of millennials aged 18 to 29, it was concluded that the priority values that the millennials ascribe to, from highest to lowest priority are: being a good parent; having a successful marriage; helping others in trouble; owning their home; living in accordance with religious principles; earning handsomely in their career; having a lot of free time and becoming very popular. Generally speaking, millennials are a generation of young people who share values similar to those of the previous generations. They are empathic, familial, appreciate careers, are willing to help; they aspire to have a family, and seek free time.

Should we analyze the members of this generation from the aspect of their behavior and attitude towards work, we could say that they are capable of doing more tasks at the same time, and that they are very educated and entrepreneurial. They are not afraid of challenges; they are ready to face completely unexpected situations and tasks, trying to find the best solution in the shortest possible time. Different authors cite high level demandingness as one of the characteristics of the millennial generation, while also enjoying a high degree of trust (Glass, 2007; Krasulja et al., 2015).

Observing the Millennial Generation (Generation Y) and its characteristics, one can notice that the members of this generation have a lot of similarities with their predecessors, members of the Baby Boomer Generation (Generation X). They, like the previous generation, are prone to team work, accept differences, are optimistic, and accept changes easily. Also, they highly value flexibility and independence, and they strive to realize the greatest balance possible between their business and private lives (Jenkins, 2007; Krasulja et al., 2015).

Some of the general demographic trends are depicted in the following Table 1.

Table 1: Predictions on Demographic Change in the Workforce

\begin{tabular}{|l|l||}
\hline The workforce in the Year 2000 & The workforce in the year 2020 \\
\hline $\begin{array}{l}\text { The population, and consequently, the available } \\
\text { labour force grows much slower than in the } \\
\text { previous period. The birth rate in developed } \\
\text { countries has been decreasing for many years. }\end{array}$ & $\begin{array}{l}\text { Planning the workforce becomes extremely } \\
\text { unpredictable in line with the conditions in } \\
\text { the business environment. }\end{array}$ \\
\hline $\begin{array}{l}\text { The percentage of women and ethnic minorities in } \\
\text { the total labour force is steadily growing. }\end{array}$ & $\begin{array}{l}\text { The percentage of women in the total labor } \\
\text { force could reach 50 percent. }\end{array}$ \\
\hline $\begin{array}{l}\text { The labour force is getting older and the percentage } \\
\text { of young employees is very low. }\end{array}$ & $\begin{array}{l}\text { There is a growing percentage of young } \\
\text { people, as well as middle-aged employees } \\
\text { who are in line for promotions. }\end{array}$ \\
\hline $\begin{array}{l}\text { Given the aging workforce, fewer people are } \\
\text { willing to change jobs, to retrain, and so on. } \\
\text { Organizations have been forced to find different } \\
\text { ways to adapt. }\end{array}$ & $\begin{array}{l}\text { Organizations are obliged to provide different } \\
\text { programs and benefits to older employees. }\end{array}$ \\
\hline $\begin{array}{l}\text { Globally, an increasing number of immigrants } \\
\text { work in organizations around the world. }\end{array}$ & $\begin{array}{l}\text { The labor force at the global level is almost } \\
\text { completely ethnically diversified. }\end{array}$ \\
\hline
\end{tabular}

Source: Johnston, W. B., \& Packer, A. H. (1987). Workforce 2000: Work and workers for the twentyfirst century. Indianapolis, IN: Hudson Institute, Inc. Judy, R. W., \& D’Amico, C. (1997). Workforce 2020: Work and workers in the 21st century. Indianapolis, IN: Hudson Institute, Inc.

It is worth noting that the millennial generation is more educated than the previous one. They wish to work only meaningful jobs, to feel respected and seen, and it is extremely 
important for them to participate in the mission of the organization where they work. It can be said that they prioritize this over high earnings. They also prefer to work on a flexible timetable - they like to work, but when and where they choose. Many of them simultaneously do volunteer work or engage in some form of philanthropic activity (Dowd-Higgins, 2013; Krasulja et al., 2015).

The millennial generation fits well with all the changes that have emerged as a result of globalization in the digitalization era. This generation is itself the bearer of numerous changes. They learn very quickly from a variety of sources that are now easier than ever to find on the Internet. Google search is an irreplaceable tool in that sense. Webinars, podcasts, social networks, and tutorials are forms preferred by the millennials, primarily because they are able to learn as efficiently as possible, and to acquire modern skills necessary for positioning in today's labour market.

As a result, millennials change jobs often, and without difficulty. They seek challenges and successfully deal with them because they are primarily suited to their living conditions and values. They are very direct in their approach and much clearer than the baby boomers in letting the employer know whether they are happy at work, which makes it easier to understand their value system. They appreciate managers who are positive and open to collaboration. They avoid rigid structures and bureaucratic organizations. This also greatly facilitates the employer's knowledge of their value system (Murphy, 2007; Krasulja et al., 2015).

\section{THE USE OF DIGITAL MARKETING TECHNOLOGIES IN THE CLASSROOM}

Digital marketing technologies are a complex multidisciplinary field that derives knowledge from business economics, psychology and information technologies. In practice, more often than in academia, the following terms are identified: social network marketing, digital marketing, internet marketing and E-marketing (Shaltoni, 2016). The American Marketing Association (AMA, 2019) does not differentiate between the above terms, but instead offers a definition of online marketing according to which the marketing campaign is based on the Internet and e-mail, and can include advertising banners on the site, e-mail marketing, search engine optimization, e-commerce and other tools. Thanks to Internet logistics (computers, mobile phones, tablets, television, etc.), E-marketing has the ability to include potential digital content via texts, audio and video (Strauss and Frost, 2014). Social networks are defined as a group of Internet-based applications founded on Web 2.0's technological foundations, owing to which it is possible to create and exchange different forms of content (Kaplan and Haenlein, 2010).

It is precisely digital technologies that have influenced not only the business environment but also the behaviour of consumers and the society as a whole, and therefore the field of education, the manner in which marketing lecturers teach and the type of expectations of students attending marketing classes (Duffy and Ney, 2015). It is essential that marketing lecturers are aware of the necessity of using digital technologies in teaching and to approach them very carefully since education requires much more than just using new technologies in teaching (Phillip and Garcia, 2013).

The mission of marketing academics is to provide millennial students with ways of critical marketing thinking and knowledge on the efficient use of digital technology in a marketing environment. After marketing education, students should be equipped with a transferable set of knowledge that enables them to work smoothly in a digital marketing environment. Due to technological progress, it is important to see the importance of the connection between the educational environment and, ultimately, the one on which the marketing industry focuses. Thanks to such a view, it will be easier and more efficient to 
implement all those technological skills that will, as shown by practice, be required of marketing graduates. Only in this way can the gap between marketing education at higher education institutions and the actual requirements in the labour market be reduced. In overcoming this, it is certain that the focus is shifting from 'teaching as instruction' to 'studentcentered learning' (Corrin, 2014).

The focus in marketing teaching should be on micro-use of digital technology tools such as social networks, blogs, wikis, etc. In a variety of reasons why today's millennial students wish to use social networks in teaching, and from the offered choices between fun, information, easier identification and social interaction, this is the latter that is most common (Kilian et al., 2012). Interestingly, in a series of social networks, students point out Facebook and Twitter as the most effective social tools for expressing ideas. In addition, YouTube is a social network that enables students to share a discussion, and is also a valuable means of presenting and sharing new content. Marketing educators can use this social network as an excellent analytical tool for the development of certain debates in the course of teaching. Further, in terms of importance, the use of certain sites and blogging comes right after the aforementioned. Observing real business situations in marketing classes is a very effective way to see how marketing practitioners use social networks. Studies show that students like having an opportunity to learn through practical workshops or have their work directly posted on some social network (Crews and Stitt-Ghodes, 2012). Through the use of such workshops, students are in a position to collaborate as a group and form a particular form of synergetic thinking, and, lastly, to present their conclusions through multiplied digital channels.

Some studies support the fact that students use only those digital technologies they are familiar with and with which they already have some positive experiences (Kilian et al., 2012). Also, there are situations where students use digital technologies in their private lives, but they are not exactly thrilled using them in more formal situations, for example, during marketing class. It is noteworthy that not all students are present on all social networks, and that they are not always willing to use their private profiles for educational purposes (Williams et al., 2012). In this sense, we are talking about the potential point of saturation.

The engagement of students during classes is of great importance for the entire educational experience because it represents a form of effort and a student's desire to actively participate in the class. Student engagement is an important element of the learning process, and some of the scientific studies have shown that there is a positive correlation between the use of social networks and the students' engagement (Junco et al., 2011). Marketing educators should recognize the special relationship that exists between their students' motivation and the manner in which they adopt the entire learning process (Taylor et al., 2011). As the importance of various social networks to the millennial population is well known, using them for communication with marketing lecturers is also suggested.

In fact, it is believed that students are more easily integrated through social interaction, gain a sense of belonging, communication and ease of attachment, which subsequently influences both their relationship with fellow-students, and with the lecturer. The students prefer digitally formatted discussion to face-to-face discussion during a traditional class when it comes to interaction with their teachers (Owens and Price, 2010).

While marketing educators are adopting new ways to integrate modern digital technologies into their teaching effectively, it remains to be seen in what measure their content, and use of social networking tools are implemented. A with the aforementioned example regarding students, it is believed that although marketing teachers use social networks in their private lives, it is not certain how much they are willing to implement their use in teaching 
(Tuten and Marks, 2012), despite the fact that the connection of digital technologies and marketing is beyond doubt.

\section{CONCLUSION}

Millennial students are happy to accept modern digital technologies in the teaching of marketing. Teachers should be careful in choosing social networks depending on their teaching plans, as students are not likely to unanimously accept all offered social networks within them. Universities should strategically incorporate social networks as compulsory tools not only in the field of marketing, but also in other related disciplines. In other words, the introduction of social networks in the teaching of marketing is considered a positive acceptance of modern technological tendencies and makes for a complete educational experience for all the millennial students.

The 21 st century certainly posed new challenges in the marketing classrooms of higher education institutions. The role of the university as the primary provider of services was significantly changed, as was the role of the student, who now, for the first time, appears in the role of a partner, and not a mere user of educational services. This puts the pedagogical side of marketing education in a complex position - to be more flexible and adjust its programs and ways of placing its services in line with market requirements. It is necessary in this situation to look at the actual needs of the market - marketing companies and agencies. Graduates with real experiences in social networking are important to them, regardless of whether it is tracking consumer behavior that they require, or carrying out a complex marketing campaign.

In order to successfully adopt pedagogical acceptance of new digital technologies in marketing teaching, it is essential to understand the perspectives of all three involved parties: a student, a marketing lecturer, and a marketing company. Only in this way can one expect a more efficient subsequent implementation of digital applications and platforms, which will benefit society as a whole. 


\section{REFERENCES}

AMERICAN

MARKETING

ASSOCIATION

DICTIONARY, http://www.marketingpower.com/_layouts/Dictionary.aspx?dLetter=E (Date Accessed 4 February 2019)

ANDEVSKI, M., and VUČKOVIĆ, Ž., 2012, Daroviti u diskursu digitalnog optimizma i nihilizma. In G. Gojkov \& A. Stojanović (Eds.), Darovitost i moralnost (pp. 91-102). Vršac, Arad, Bitolj, Ptuj: Visoka škola strukovnih studija za obrazovanje vaspitača. http://www.uskolavrsac.edu.rs/Novi\%20sajt\%202010/Dokumenta/Izdanja/17\%20Okr ugli\%20sto/08\%20Andevski,\%20Vuckovic.pdf (Date Accessed 11 November 2019).

AVILES, M., and EASTMAN, J., 2012, Utilizing technology effectively to improve Millennials' educational performance: An exploratory look at business students' perceptions, Journal of International Education in Business, 5, 96-113.

BROCATO, E.D., WHITE, N.J., BARTKUS, K., and BROCATO, A.A., 2015, Social media and marketing education: a review of current practices in curriculum development, Journal of Marketing Education, 37 (2), 76-87.

CORRIN, L., 2014, Examining digital natives: An investigation of university students' engagement with technology (Doctoral dissertation). University of Wollongong, New South Wales, Australia.

CREWS, T.B., and STITT-GHODES, W.L., 2012., Incorporating Facebook and Twitter in a service-learning project in a business communication course, Business Communication Quarterly, 75 (1), 76-79.

DOWD-HIGGINS, C., 2013., How to play together in the multigenerational sandbox at work. Huffington Post.

DUFFETT, R. G., and WAKEHAM, M., 2016, Social media marketing communications effect on attitudes among millenials in South Africa, The African Journal of Information Systems, 8 (3), Article 2.

DUFFY, K., and NEY, J., 2015, Exploring the divides among students, educators, and practitioners in the use of digital media as a pedagogical tool, Journal of Marketing Education, 37 (2), 104-113.

GIKAS, J., and GRANT, M.M., 2013, Mobile computing devices in higher education: Student perspectives on learning with cell-phones, smartphones \& social media, Internet and Higher Education, 19, 18-26.

GLASS, A., (2007), Understanding generational differences for competitive success. Industrial and Commercial Training, 39 (2), 98-103.

HARGITTAI, E., and LITT, E., 2011, The tweet smell of celebrity success: Explaining variation in Twitter adoption among a diverse group of young adults, New Media \& Society, 13, 824-842.

IQBAL, S., 2016, Insights of school head about marketing education services through digital media, Journal of Education and Educational Development, 3, (1), 52-73.

JENKINS, J., 2007, Leading the four generations at work, (online), from http://www.amanet.org/movingahead/editorial.cfm?Ed=452 (Date Accessed: 4 November 2018). 
JOHNSTON, W. B., and PACKER, A. H. (1987), Workforce 2000: Work and workers for the twenty-first century. Indianapolis, IN: Hudson Institute, Inc. Judy, R. W., \& D’Amico, C. (1997). Workforce 2020: Work and workers in the 21st century. Indianapolis, IN: Hudson Institute, Inc.

JUNCO, R., HEIBERGER, G., and LOKEN, E., 2011, The effect of Twitter on college student engagement and grades, Journal of Computer Assisted Learning, 27, 119-132.

KPLAN, A.M., and HAENLEIN, M., 2010, Users of the world, unite! The challenge and opportunities of social media, Business Horizons, 53, 50-63.

KERSTEN, D., 2002, Today's generations face new communication gaps, from http://www.kcnawic.org/uploads/4/4/7/2/4472081/04-15-2014.pdf, (Date Accessed 11 January, 2019).

KILIAN, T., HENNINGS, N., and LANGNER, S., 2012, Do millennials read books or blogs? A media usage typology, Journal of Consumer Marketing, 29, 114-124.

KRASUlJA, N., RADOJEVIĆ, I., VASILJEVIĆ-BLAGOJEVIĆ, M., and JANJUŠIĆ, D., 2015, Multigeneracijska radna snaga - prednost ili nedostatak za suvremene organizacije. Praktični menadžment, 2, 60-66.

KRATZ, H., 2013, Maximizing millennials: The who, how, and why of managing Gen Y. MBA@UNC Blog. https://onlinemba.unc.edu/blog/geny-in-the-workplace (Date Accessed 21 February, 2019)

MAMULA T., RADOJEVIC I., and SLIJEPCEVIC M., 2016, Innovation, Competitiveness and Sustainable Development conference; ICSD 2016, Faculty of Management, Metropolitan University, Belgrade

MISHRA, S., 2011, Consumers' response towards marketing through social networking sites in India, International Journal of Indian Culture and Business Management, 4 (4), 436452.

MURPHY, S., 2007, Leading a Multigenerational Workforce, Washington, D.C.: AARP.

NEIER, S., and ZAYER, L. T., 2015, Students' perceptions and experiences of social media in higher education, Journal of Marketing Education, 37 (3), 133-143.

OWENS, J.D., and PRICE, L., 2010, Is e-learning replacing the traditional lecture? Education + Training, 51, 353-369.

PHILLIP, T.M., and GARCIA, A.D., 2013, The importance of still teaching the iGeneration: New technologies and the centrality of pedagogy, Harvard Educational Review, 83 (2), 300-319.

PRENSKY, M., 2001, Digital natives, digital immigrants, On the Horizon, 9 (5).

RADOJEVIC I., KRASULJA N., and VASILJEVIC-BLAGOJEVIC M., 2014, The expectations from studies among members of millennial generation. Proceedings. Vol. 2. Belgrade: Faculty of Business Studies and Law; Faculty for Strategic and Operational Management, 793-799.

REYNOLDS, E., 2008, Ask Gen Y Survey, Available from http://www.askgeny.co.uk. (Date Accessed 11 January 2019).

RIZVI, S.A.A., 2011, The uniqueness of educational marketing, Educational Quest-An International Journal of Education and Applied Social Sciences, 2 (2), 197-201. 
RINALDO, S., LAVERIE, D.A., TAPP, S., and HUMPREY, W., 2013, The benefits of social media in marketing education: Evaluating Twitter as a form of cognitive flexibility hypertext, Journal for Advancement of Marketing Education, 21, 16-26.

SAGO, B., 2010, The Influence of Social Media Message Sources on Millennial Generation Consumers, International Journal of Integrated Marketing Communications, 2 (2), 718.

SHALTONI, A. M., 2016, E-marketing education in transition: An analysis of international courses and programs, The International Journal of Management Education, 14, 212218 .

STRAUSS, J., and FROST, R., 2014, E-marketing, Boston: Prentice Hall.

TAPSCOTT, D., 1999, Growing up digital: The rise of the net generation, New York: McGraw - Hill.

TAYLOR, S.A., HUNTER, G.L., MELTON, H., and GOODWIN, S.A., 2011, Student engagement and marketing classes, Journal of Marketing Education, 33 (1), 73-92.

TUTEN, T., and MARKS, M., 2012, The adoption of social media as educational technology among marketing educators, Marketing Education Review, 22 (3), 201-214.

VALCOUR, M., 2013, Hitting the intergenerational sweet spot. HBR Blog Network. http://blogs.hbr.org/2013/05/hitting-theintergenerational, (Date Accessed 11 January 2019)

VEEN, W., 2006, Homo zappiens: Growing up in a digital age. London: Network Continuum Education.

WILLIAMS, D.L., CRITTENDEN, V.L., KEO, T., and McCARTY, P., 2012, The use of social media: An exploratory study of usage among digital natives, Journal of Public Affairs, 12 (2), 127-136.

ZULA, K., YARRISH, K.K., \& PAWELZIK, W., 2011, An analysis of the differences between student age and social networking utilization within a school of business, American Journal of Business Education, 9, 37-42.

\section{Internet sources:}

http://www.statista.com, (Date Accessed 15 April 2019).

http://www.huffingtonpost.com/carolinedowdhiggins/how-to-play-togetherint_b_2989568.html (Date Accessed 11 January 2019). 
POPOVIC SEVIC \& SLIJEPCEVIC / The Digital Necessity in Marketing Education to the Millennial Generation 